\title{
AID: ITS UTILITY AND ITS FUTURE
}

\section{by Robert Sutcliffe*}

Enoch Powell remarks that 'there is no electoral pull in "aid"'; to most people "'aid" is positively and increasingly unpopular'; hence, perhaps his opposition to it. But however politically opportune, his views have a certain consistency. Aid in the post-colonial world is seen in various ways as a replacement for gunboats - serving a different purpose in the view of liberal aid supporters, just as another weapon of foreign policy in the view of conservative aid supporters (including most Western governments) and of radical critics.

In the past Powell, in his consistency, has been against both gunboats and aid: he has opposed Eden at Suez, Wilson and Heath east of it. He appears to be'ieve (wrongly) that what happens in the Third World is not relevant to Western interests; this littlest Englander of all implies that the people of the Third World can be safely left to stew in their own underdevelopment and corruption until they perceive that 'the only truly beneficent gift we have to offer is the example of what made the West productive - capitalism and enterprise'.

By contrast, part of Myrdal's theme is that 'the fact that South Asia's freedom of action is now limited will .... make a

*Fellow of Jesus College, Oxford. 
reversal of (existing) trends more difficult in the future and, in any case, impossible of accomplishment without more radical government intervention than in the past' (p.64l). The self-deception which can allow Powell to embrace Myrdal's views as his own is truly breathtaking.

The two are at least as far apart on aid. Western style economic growth, argues Powell, is impossible without revolution: 'if such a revolution were to occur, it would render "aid" superfluous; unless and until it does, "aid" implies an arrogant presumption on the part of Western countries, an ambition to substitute one's own values for those of others'. But Powell's indifference in the face of mass poverty, until the miraculous conversion to capitalist virtues (shown by Myrdal to have very limited use), is itself patently arrogant. What presumably worries Powell is that aid has tended to support state - rather than private - capitalism in South Asia. Unlike Powell, Myrdal is a supporter of aid and would rightly consider aid more useful the more his (not Powell's) social revolution got going.

But Myrdal's strictures against aid as it has been used are in my view justified. The efficacy of aid depends (among other things) on the nature of the society to which it goes; thus in corrupt and inefficient societies 'some aid simply feeds corruption and maintains inefficiency' (p.636). Aid has not been used to promote or support social revolution but as the instrument of a foreign policy obsessed with "stability": 'In the interest of "stability", several corrupt governments in South Asia have received substantial foreign assistance. These facts of life make it very difficult for South Asians to undertake those economic and political reforms essential for stimulating growth and weeding out favouritism and bribery. Any pressure for internal reforms the donor country might apply can easily be thwarted by the threat of collapse, the very thing that foreign aid was designed to prevent' (p.637). The element of political blackmail in the aid relationship is not one-sided; it involves the donor and the regime of the underdeveloped country, but seldom its people.

Any critique of economic aid contending that it is a simple weapon of the rich to bribe or blackmail the poor is intpossibly crude. Very complex political mechanisms are at work. Myrdal continually emphasis the crucial connection between the political and social system and the possibilities of 
economic progress. He says less about the reverse relationship - how economic developments might effect social and political changes. Barrington Moore has speculated in this direction: 'If the agrarian programme of the present Indian government fails to solve India's food problem..... a political upheaval of some sort will become highly likely. But it will not necessarily take the form of a communist-led peasant revolution. A turn to the right or fragmentation along regional lines, or some combination of these two, seems much more probable in the light of India's social structure' (Social Origins of Dictatorship and Democracy, p.482). In practice what has been relevant here is the combination of the Indian government's agrarian programme and American food aid. The links between food aid and political stability are very complex. The absence of food aid might have hastened political upheaval; or, as many people have maintained, the absence of aid might have forced a more radical and successful programme on the government.

Writing about Pakistan, Gustav Papanek has concluded that 'at least over the next decade, an end to loans and grants would stop any substantial increase in per capita income under Pakistan's present economic and political system' (Pakistan's Development, p.240, my emphasis). This is not to say for certain that the same rate of growth could be achieved under any other possible political system. It makes clear, however, that there is an involved relationship between aid, the rate of economic progress, economic policy and the political system. Where aid is small, its removal may allow growth to continue at the same rate with no more than, say, a marginal increase in taxes. Where aid is great, its removal could involve farreaching political changes which are hard to predict; some of these may be desirable, others undesirable, regardless of the motives for the aid.

These are facts about aid, not in themselves a criticism of it. But some conclusions do emerge from these facts. First, the step from ' $\mathrm{X}$ gives aid to $\mathrm{Y}$ ' to 'aid prevents desirable social change' is not a simple one; the intervening premisses must be stated. It must be a matter for careful judgment whether in practice the political effects of aid have been good or bad and whether its ending would lead (perhaps by a very devious route) to more progressive social structures. Second, where aid does disguise the need for reforms, it can, 
as Myrdal shows, entrench the forces opposed to reform; "stability" may then only be achievable at the cost of progressively expanding aid commitments which no Western donor seems at present prepared for. Third, while Myrdal supports multilateral aid in which 'the political element is less pronounced' (p. 637), aid from international sources is as much tied up with politics as bilateral aid, though the connection may be less crude. The World Bank as creditor must be as interested in "stability" as any government - perhaps more so, as it comes to rely for its capital exclusively on borrowing in the capital markets of the West; its very existence depends on its ability to honour its debts. It can less afford defaults than governments; on the other hand, it is not so obliged to react against the expropriation of private capital by cutting off aid.

McNamara's announcement on September 30 of a massive World Bank programme and the virtual certainty of a Nixon/ Wallace US Congress make it probable that for the next five years most aid will be international. Could a new regime of international aid afford to concentrate its assistance upon those countries which are making genuine progress towards a rapid change in social, political, and economic power? If so, (though I am pessimistic), aid could redeem itself. It is the notion of aid as a reward for "good" behaviour which is the real arrogance, not the idea of aid itself. 